\title{
Mesothelioma Register 1967-68
}

\author{
MORRIS GREENBERG and T. A. LLOYD DAVIES \\ Employment Medical Advisory Service, Department of Employment, 1-13 Chepstow Place, \\ London W2
}

Greenberg, M., and Lloyd Davies, T. A. (1974). British Journal of Industrial Medicine, 31, 91-104. Mesothelioma Register 1967-68. A register of mesothelioma cases is maintained by the Department of Employment, Medical Services Division (now Employment Medical Advisory Service). This paper describes an investigation of $\mathbf{4 1 3}$ notifications to the Register in 1967-68 from England and Wales and Scotland.

Cases were regarded as 'definite' when histological confirmation of diagnosis had been obtained, either by hospital pathologists, or by the UICC Panel of Pathologists, to whom pathological material was submitted whenever possible. Two hundred and forty-six cases were accepted as 'definite' and 76 cases were regarded as 'definitely not' mesothelioma. The remainder were classified as 'undecided' or 'insufficient pathological material'. Thirty-five of the 76 cases definitely not mesothelioma had nevertheless been so described on death certificates.

The investigation carried out covers clinical aspects, survival, and evidence of exposure to asbestos. Twelve per cent of definite mesotheliomata were of peritoneal origin. The age range was 21 to 87 years, but, in general, mesothelioma occurred at an earlier age than 'carcinoma of bronchus and lung' or 'all malignant tumours' in the Registrar General's statistical mortality tables.

Concomitant asbestosis and the finding of asbestos bodies or pleural plaques occurred as frequently in those cases classified as definitely not mesothelioma as in confirmed cases.

Occupational exposure to asbestos was found in $68 \%$ of definite cases, apparently significantly more frequently than in those definitely not mesothelioma, but there was observer bias. The interval between first exposure and death from mesothelioma exceeded 25 years in $85 \%$ of cases but was only three and a half years in one case. The duration of exposure varied widely: in $12 \%$ of cases it was under five years. The type of asbestos could be ascertained in so few cases that it was impossible to assess the rôle of crocidolite in aetiology. There were 38 definite cases in which no history of any exposure to asbestos could be obtained.

Definite mesotheliomata showed marked clustering in areas where there is substantial industrial use of asbestos. Whether this should be interpreted as evidence of causation or an effect of heightened awareness in these areas cannot be deduced from this study. Evidence is quoted suggesting that the observed annual incidence of approximately 120 definite mesotheliomata in England, Scotland, and Wales may considerably understate the true prevalence.

Diffuse or malignant mesothelioma of the pleura and peritoneum, although rare, has been sought for increasingly in the past decade. The reported association with asbestos exposure (Wagner, Sleggs, and
Marchand, 1960) gave impetus to the enquiry. For some years the Pneumoconiosis Unit of the Medical Research Council had recorded cases of mesothelioma reported to them. By 1966 a register of some 
200 cases which had been diagnosed in Britain in the previous 15 years, with histological confirmation of diagnosis, was in their possession with the help of information resulting from an enquiry (Smither, Gilson, and Wagner, 1962). In that year the register was handed over to the Medical Branch of HM Factory Inspectorate (now Employment Medical Advisory Service, Department of Employment).

The objects of the register were stated in the Senior Medical Inspector's Advisory Panel Memorandum (1968):

$i$ to record the annual number of deaths from mesothelioma of the pleura or peritoneum associated with asbestos exposure;

ii to ascertain trends in the prevalence rates;

iii to discover, if possible, tumours occurring without any exposure to known or suspected occupational causes;

iv to provide part of the evidence on which preventive measures should be based.

This paper presents the results of investigations into cases notified to the register from England and Wales and from Scotland for the period 1 January 1967 to 31 December 1968. Preliminary results have been published elsewhere (Lloyd Davies, 1970) and the present report relates to information available to May 1972.

\section{Plan of investigation}

The Registrars General for England and Wales and for Scotland forwarded copies of $(a)$ death certificates which included a diagnosis of mesothelioma of pleura or peritoneum and (b) Cancer Bureaux registrations with a diagnosis of malignant mesothelioma. Pneumoconiosis Medical Panels also notified cases of mesothelioma which were subject to claims for benefit under the National Insurance Acts or otherwise came to their notice. Information about other cases was received from chest physicians, surgeons, pathologists, and coroners. The majority of cases were notified from two or more sources.

The Central Ethical Committee of the British Medical Association agreed that tracing of cases by medical advisers should take place only after the prior approval of the patient's medical attendant. In the event, approval was given in all cases. Where possible histological slides or blocks of histological material were obtained: these were submitted to the Union International contre le Cancer (UICC) Panel of Pathologists (see Appendix).

\section{Diagnostic criteria}

A definitive diagnosis was made only when histological proof was available. Borrowed material was referred to the UICC Panel of Pathologists together with an abstract of occupational and clinical histories and of necropsy findings. The histological and histochemical features of mesothelial tumours have been discussed by UICC panel pathologists (Wagner, Munday, and Harington, 1962; Hourihane, 1964; McCaughey, 1965; Whitwell and Rawcliffe, 1971) and the criteria employed by the UICC panel to derive a consensus opinion appears in the Appendix. Where material could not be borrowed the reports of consultant pathologists were examined. Where several pathologists gave varying opinions on a section and it was not possible to refer material to the UICC panel, the majority decision was taken. The occupational history was often sought after the histological diagnosis had been made by the nonpanel pathologists. Diagnoses made by these pathologists were allocated to the following groups:

'Definite', where in the view of the pathologist, based on adequate histological material supported by the gross appearance at thoracotomy, laparotomy or necropsy, mesothelioma was the diagnosis of election.

'Undecided', where the material examined and other features while compatible with a diagnosis of mesothelioma did not permit the pathologist to make a firm diagnosis (this corresponds to the category 'undecided' finally employed by UICC pathologists).

'Insufficient histological material', where the pathologist was dissatisfied with the material, or where neither histological nor necropsy material were ever examined.

'Definitely not', where a definite alternative diagnosis was made by the pathologist.

When tumour was present in both thorax and abdomen the site stated in the analysis is that given by the pathologist as the primary site. Where the death certificate differed from the necropsy report, the latter was accepted.

\section{Asbestos exposure history}

Where possible living subjects were interviewed, but for deceased subjects the relatives were interviewed in the first instance. Occupational histories were also sought from coroners and from former employers and workmates. The initial classification was made by the investigating medical adviser who may or may not have been aware of the interim diagnosis and was rarely aware of the final diagnosis. The final classification was made by a second medical adviser in consultation with the first, and often this took place before the final diagnosis had been received.

\section{Occupational exposure}

Occupational exposure to asbestos was defined as follows:

'Definite', where the job involved full-time or intermittent handling of asbestos or asbestos- 
containing compounds, or where the subject worked in an atmosphere contaminated by asbestos dust.

'Possible', where the job description was too imprecise to be certain, but there was a strong suspicion of exposure to asbestos.

'None', where, after exhaustive enquiry, no occupational exposure could be presumed.

'Unknown', where adequate industrial details were not forthcoming. If possible the duration of exposure was recorded and the length of time before death that exposure ceased. The duration in intermittent exposures is presented as a cumulative figure.

\section{Domestic exposure}

Domestic exposure was considered as positive when a history that members of a subject's family had come home visibly contaminated by asbestos was obtained.

\section{Hobby exposure}

Hobby exposure was recorded in several householders or smallholders who gave a history of sawing asbestos sheeting for the construction of outhouses, garages, and chicken houses.

\section{Neighbourhood exposure}

Neighbourhood exposure was recorded when subjects lived within one mile of an asbestos factory or shipyard using asbestos but had no occupational exposure.

\section{Other evidence of asbestos exposure}

Asbestos exposure was presumed in cases showing evidence of asbestosis (either on chest radiograph or at necropsy) and in those in whom asbestos bodies or fibres had been demonstrated by light microscopy in sputum, lung sections, or fluid expressed from the cut surface of the lung. The reported finding of pleural plaques at operation or necropsy, or evidence of plaques on the chest radiograph, was regarded as suggestive of asbestos exposure.

\section{Results}

For the years 1967 and 1968, a total of 413 cases was reported to the mesothelioma register. Of these, 168 were first notified by death certificate as having died in those years and a further 166 were notified in life and died during this period. Seventy-nine subjects notified survived the period of study.

Death certificates were the most important source of notification comprising $53.5 \%$ of all notifications in 1967 and $77.8 \%$ in 1968 . In the absence of death certifications, further notifications were received from cancer bureaux, $45(26.5 \%)$ in 1967 and $33(13.6 \%)$ in 1968. Further groups of cases were reported exclusively by other sources (physicians, surgeons, and pathologists), 31 (18.2\%) in 1967 and $18(7.4 \%)$ in 1968. Three other cases otherwise unreported were reported in each year by the Pneumoconiosis Medical Panels. A total of 170 notifications were made in 1967 and 243 in 1968.

\section{Pathological diagnosis}

In Table 1 the notifications are shown categorized according to the criteria of diagnosis. The correlation between histological diagnosis and the diagnosis given on the death certificate was weak. Of the 246 cases accepted as 'definite', only 186 were so described on death certificates. On the other hand, of 76 cases 'definitely not mesothelioma' death had been attributed to mesothelioma on the death

TABLE 1

Notifications to Mesothelioma Register analysed by Diagnostic Criteria and Site of Tumour

\begin{tabular}{|c|c|c|c|c|c|c|}
\hline & \multirow{2}{*}{$\begin{array}{l}\text { Site of } \\
\text { tumour }\end{array}$} & \multicolumn{4}{|c|}{ Diagnostic category $^{1}$} & \multirow{2}{*}{ Total } \\
\hline & & Definite & Undecided & $\begin{array}{l}\text { Insufficient } \\
\text { material }\end{array}$ & $\underset{\substack{\text { Definitely } \\
\text { not }}}{ }$ & \\
\hline UICC Panel & $\begin{array}{l}\text { Pleura } \\
\text { Peritoneum }\end{array}$ & $\left.\begin{array}{r}118 \\
16\end{array}\right\} 134$ & $\left.\begin{array}{c}14 \\
4\end{array}\right\} 18$ & $\left.\begin{array}{c}12 \\
1\end{array}\right\} 13$ & $\left.\begin{array}{r}23 \\
7\end{array}\right\} 30$ & $\begin{array}{r}167 \\
28\end{array}$ \\
\hline Other pathologists & $\begin{array}{l}\text { Pleura } \\
\text { Peritoneum }\end{array}$ & $\left.\begin{array}{l}98 \\
14\end{array}\right\} 112$ & $\left.\begin{array}{r}26 \\
2\end{array}\right\} 28$ & $\left.\begin{array}{c}32 \\
0\end{array}\right\} 32$ & $\left.\begin{array}{r}42 \\
4\end{array}\right\} 46$ & $\begin{array}{r}198 \\
20\end{array}$ \\
\hline Total & $\begin{array}{l}\text { Pleura } \\
\text { Peritoneum }\end{array}$ & $\begin{array}{r}216 \\
30\end{array}$ & $\begin{array}{r}40 \\
6\end{array}$ & $\begin{array}{r}44 \\
1\end{array}$ & $\begin{array}{l}65 \\
11\end{array}$ & $\begin{array}{r}365 \\
48\end{array}$ \\
\hline All cases & & 246 & 46 & 45 & 76 & 413 \\
\hline
\end{tabular}

1See text for definition 
certificates in 35 instances. The pathological diagnoses in these $\mathbf{3 5}$ cases were:

Carcinoma of bronchus .. $\quad$. . . .

Carcinoma, origin unstated $\quad . \quad$..

Secondary adenocarcinoma (primary $\begin{array}{llllll}\text { unstated) } \quad . . & \ldots & \ldots & \ldots\end{array}$

Not mesothelioma (no other diagnosis)

Myelomatosis .. $\quad$. $\quad$.. $\quad$..

Transitional carcinoma of bladder . .

Adenocarcinoma of thyroid .. . .

Retroperitoneal fibroma or chordoma

Asbestosis and tuberculosis .. ..

Severe anaemia secondary to peptic ulcer

Malignant melanoma $\quad . \quad$.. ..

As the concordance of diagnoses between the UICC pathology panel and other pathologists was higher than $74 \%$ and the characteristics of the two groups are so similar for distribution of age at death (Fig. 1), tumour site, sex (Table 2), and survival (Figs 2 to 4), they can be treated as one. In this study peritoneal tumour represented $12.2 \%$ of all confirmed mesotheliomas (Table 2). This compares with 11 reported proportions by five authors with a range of $103.7 \%$ (of 80 cases) to $72.7 \%$ (of 22 cases) (Table 3 ). From Table 2 it can be seen that the distribution of cases between the sites was similar in the groups confirmed by UICC pathologists and by other pathologists.

\section{Sex distribution}

Table 2 shows that the ratio of mesothelioma in men and women for both UICC and other pathologists was about $5: 1$, which is similar to that for all malignant neoplasms of the respiratory system (Registrar General, 1970). The sex difference in carcinoma of the bronchus in general is thought in part to be due to difference in smoking habits (Hammond, 1966) but tobacco is not known to play a role in the aetiology of mesothelioma. If it is assumed that mesothelioma is related to asbestos

TABLE 2

246 'Definite' Mesotheliomas analysed by SeX and Site of Tumour

\begin{tabular}{|c|c|c|c|c|c|c|c|}
\hline \multirow[t]{2}{*}{ Pathologists } & \multirow{2}{*}{$\begin{array}{l}\text { Site of tumour } \\
\begin{array}{l}\text { Pleural } \\
\text { Peritoneal }\end{array}\end{array}$} & \multicolumn{2}{|c|}{$\begin{array}{c}\text { Males } \\
\text { (\% of all meso- } \\
\text { thelial tumours) }\end{array}$} & \multicolumn{2}{|c|}{$\begin{array}{l}\text { Females } \\
\text { (\% of all meso- } \\
\text { thelial tumours) }\end{array}$} & \multicolumn{2}{|c|}{ Total } \\
\hline & & $\begin{array}{l}96 \\
14\end{array}$ & $(12 \cdot 8 \%)$ & $\begin{array}{r}22 \\
2\end{array}$ & $(8 \cdot 3 \%)$ & $\begin{array}{r}118 \\
16\end{array}$ & $(11.9 \%)$ \\
\hline Other pathologists & $\begin{array}{l}\text { Pleural } \\
\text { Peritoneal }\end{array}$ & $\begin{array}{l}81 \\
10\end{array}$ & $(10.9 \%)$ & $\begin{array}{r}17 \\
4\end{array}$ & $(19.0 \%)$ & $\begin{array}{l}98 \\
14\end{array}$ & $(12.5 \%)$ \\
\hline All $\ldots$ & $\begin{array}{l}\text { Pleural } \\
\text { Peritoneal }\end{array}$ & $\begin{array}{r}177 \\
24\end{array}$ & $(12.0 \%)$ & $\begin{array}{r}39 \\
6\end{array}$ & $(13.3 \%)$ & $\begin{array}{r}216 \\
30\end{array}$ & $(12 \cdot 2 \%)$ \\
\hline
\end{tabular}

TABLE 3

Prevalence of Peritoneal Mesothelioma reported by Various Authors

\begin{tabular}{|c|c|c|c|c|c|}
\hline \multicolumn{3}{|l|}{ Authors } & $\begin{array}{c}\text { All } \\
\text { mesotheliomas }\end{array}$ & $\begin{array}{c}\text { Peritoneal } \\
\text { mesotheliomas only } \\
\text { (total) }\end{array}$ & Comment \\
\hline McEwen et al. (1970) & & . & 80 & $3(3 \cdot 7 \%)$ & $\begin{array}{l}73 \text { males and } 7 \text { females; } 2 \text { males } \\
\text { described as 'both sites' (Scotland) }\end{array}$ \\
\hline \multicolumn{2}{|c|}{ Ashcroft and Heppleston (1970) } & . & 23 & $3(13.0 \%)$ & Tyneside \\
\hline Selikoff et al. (1970) & $\cdots$ & . & 22 & $16(72 \cdot 7 \%)$ & Male insulation workers (USA) \\
\hline Thomson (1970) $\quad \ldots$ & $\cdots$ & . & 17 & $3 \quad(17 \cdot 6 \%)$ & Cape Town \\
\hline \multirow[t]{2}{*}{ Newhouse et al. (1972) } & \multirow[t]{2}{*}{. } & \multirow[t]{2}{*}{$\cdots$} & 11 & $5 \quad(45 \cdot 4 \%)$ & Females (London) \\
\hline & & & 49 & $30(61 \cdot 2 \%)$ & Males from the same factory \\
\hline Present study & . & . & 246 & $30 \quad(12 \cdot 2 \%)$ & England, Wales and Scotland 1967-68 \\
\hline
\end{tabular}


exposure it would be necessary to know the numbers of men and women at risk over the past 50 years in order to assess the relative susceptibility of the sexes to mesothelioma.

\section{Age at death}

The distribution of age at death of confirmed cases is presented in Fig. 1: there is no significant difference between cases diagnosed by the two groups of pathologists (mean age: UICC, $59.4 \pm 0.9$; other pathologists, $60 \cdot 2 \pm 1 \cdot 3$ ). For comparison the age distributions for all malignant neoplasms and for carcinoma of the bronchus and lung (Registrar General, 1970) are also shown. The mean age at death from mesothelioma is significantly younger $(\mathbf{P}<0.05)$ than that for bronchial carcinoma and 'all neoplasms'. This may be due in part or in whole either to the greater chance of identifying occupational cancers within the working age compared with the retired or to earlier death from mesothelioma associated with occupational exposure to a carcinogen.

\section{Exposure to asbestos}

In Table 4 it can be seen that of 246 confirmed cases $167(68 \%)$ had definite occupational exposure to asbestos and a further 29 were possibly exposed, either at work or at home. There were, however,
TABLE 4

Notifications to Mesothelioma Register ANALYSED BY ASBESTOS EXPOSURE

\begin{tabular}{|c|c|c|}
\hline $\begin{array}{c}\text { Asbestos exposure } \\
\text { history }\end{array}$ & $\begin{array}{c}\text { No. of } \\
\text { definite } \\
\text { mesotheliomas }\end{array}$ & $\begin{array}{c}\text { No. undecided, } \\
\text { inadequate } \\
\text { material, } \\
\text { or definite } \\
\text { alternative } \\
\text { diagnoses }\end{array}$ \\
\hline 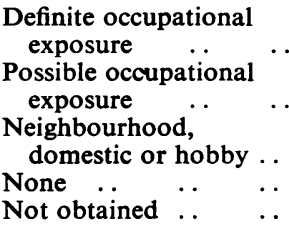 & $\begin{array}{r}167 \\
16 \\
13 \\
13 \\
38 \\
12\end{array}$ & $\begin{array}{l}63 \\
17 \\
\\
10 \\
57 \\
20\end{array}$ \\
\hline
\end{tabular}

still $38(15 \%)$ for whom careful enquiry failed to elicit any exposure whatever. In the remaining notifications ('undecided', 'inadequate material', 'definite alternative diagnosis') nearly one third were without apparent exposure, and those with definite occupational history formed only $38 \%$ of the total. The differences between these groups are significant $(P<0.001)$ but may be affected by bias towards
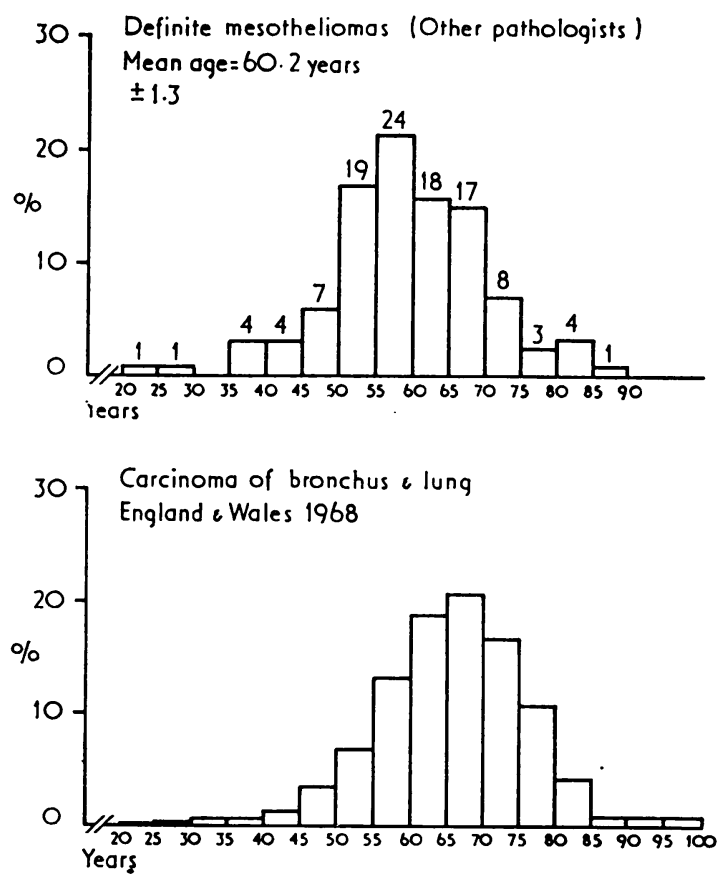

FIG. 1. Age distributions at death. 
underdiagnosis in areas without large-scale asbestos industry, or to bias on the part of the interviewers who might have been more assiduous in pursuing an asbestos association history in cases of definitive mesothelioma. Ideally it would have been desirable to conceal from interviewers the diagnosis in individual cases, but on account of limited manpower the interviewer may have been responsible for identifying cases and arranging for confirmation of diagnosis. On the other hand, the number of notifications which were not subsequently fully confirmed but had mich

TABLE 5

INDUSTRY OR JOB TITLE IN 167 'DEFINITE' Mesotheliomas With Definite OCCupational EXPOSURE TO AsBESTOS

\begin{tabular}{|c|c|c|c|c|}
\hline \multicolumn{4}{|c|}{ Industry or job } & \multirow{2}{*}{$\begin{array}{c}\begin{array}{c}\text { Number of } \\
\text { mesotheliomas }\end{array} \\
75\end{array}$} \\
\hline \multirow{4}{*}{\multicolumn{3}{|c|}{$\begin{array}{l}\text { Shipworker. . } \\
\text { Asbestos factory worker } \ldots \\
\text { Insulation worker (not marine) } \\
\text { Boiler hoüse worker (not marine) }\end{array}$}} & $\cdots$ & \\
\hline & & & . & 39 \\
\hline & & & $\ldots$ & 13 \\
\hline & & & . & 5 \\
\hline Chemical worker & . $\quad \ldots$ & . & - & 5 \\
\hline Docker . . & $\ldots$ & . & $\ldots$ & 4 \\
\hline Welding rod manu & ufacture & . & .. & 4 \\
\hline Building worker & $\ldots \quad \ldots$ & . & $\ldots$ & 3 \\
\hline Electrician .. & . & . & . & 3 \\
\hline Sack cleaner/repai & irer & . & . & 3 \\
\hline Welder/plater & . & . & . & 3 \\
\hline Battery box manu & facture & . & . & 2 \\
\hline Electricity generat & ting industry & . & . & 2 \\
\hline Gas worker & .. & $\cdots$ & . & 2 \\
\hline Railway coach/loc & comotive buil & & . & 2 \\
\hline Motor mechanic & $\cdots \quad \quad \ldots$ & $\cdots$ & $\cdots$ & 1 \\
\hline Refuse work & . & . & . & 1 \\
\hline
\end{tabular}

known asbestos exposure may have been the result of over-diagnosis because of the well-known association of mesothelioma with this occupational history thus introducing a bias in the opposite direction.

The individual occupations of confirmed cases with industrial exposure are shown in Table 5. The degree of risk associated with these occupations cannot be computed because the population exposed, over a period of 50 years, is unknown and cannot even be guessed.

Table 6 lists those subjects with mesothelioma where a history of exposure to asbestos, not occupational in origin, was obtained. Of those subjects with neighbourhood exposure, the first four lived near the same asbestos factory in a district where chest physicians have a high awareness of mesothelioma. The final four subjects listed had exposures that might be considered minimal and common experience.

In cases notified to the register by the Registrar General for England and Wales a control group was established (from 1 January 1968), the next death registration matched for age and sex but not for area being notified to the register for comparison of occupation. It was found, however, that as cases of mesothelioma were more commonly referred to coroners than were other subjects the job description was frequently qualified to indicate asbestos exposure; for example, 'plumber' or 'fitter' was further categorized as 'shipyard', whereas no such qualification appeared in the controls. Even 'housewife' and 'widow' were recorded as occupations with the disease attributed to asbestos exposure.

Ethical considerations prevented the interviewing of control subjects (or their relatives) though it is

TABLE 6

Non-occupational Asbestos Exposure Histories obtained in Cases of Mesothelioma

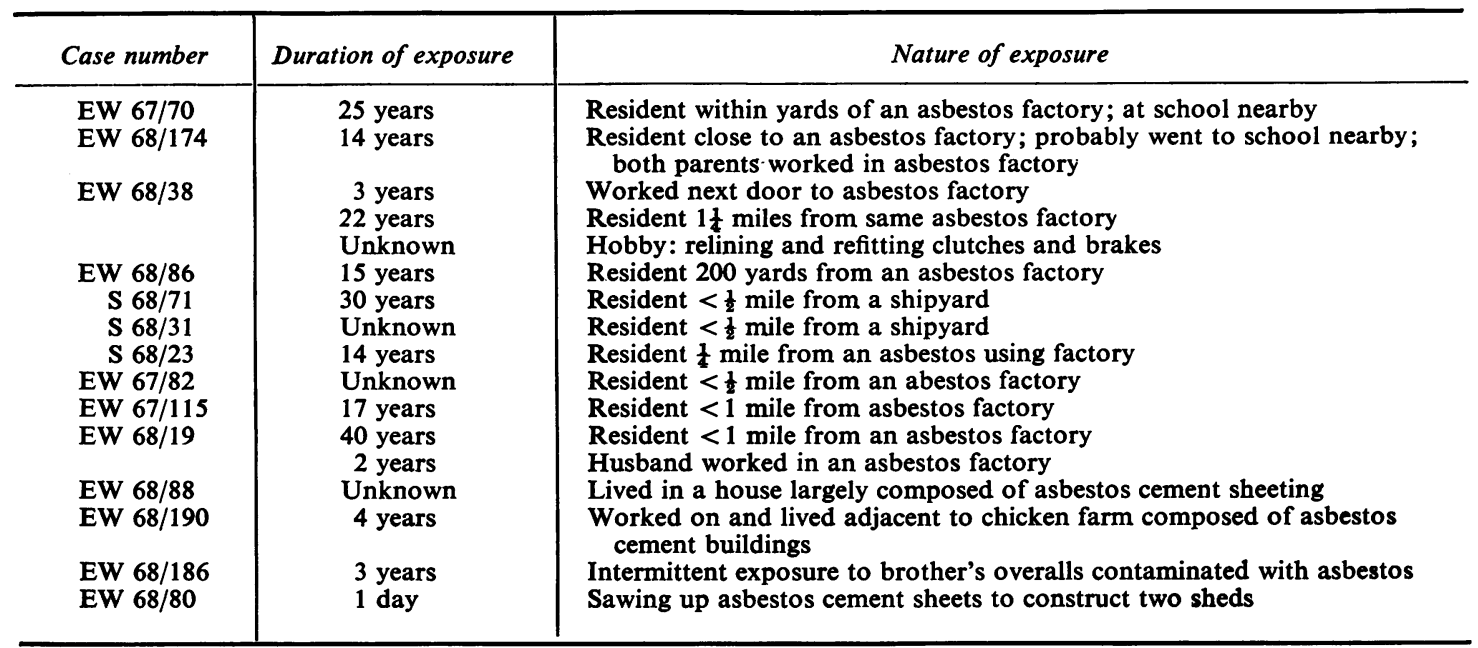


UICC panel

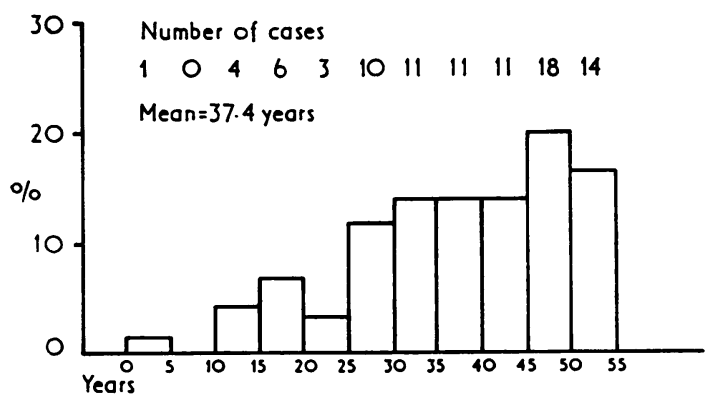

Other pathologists

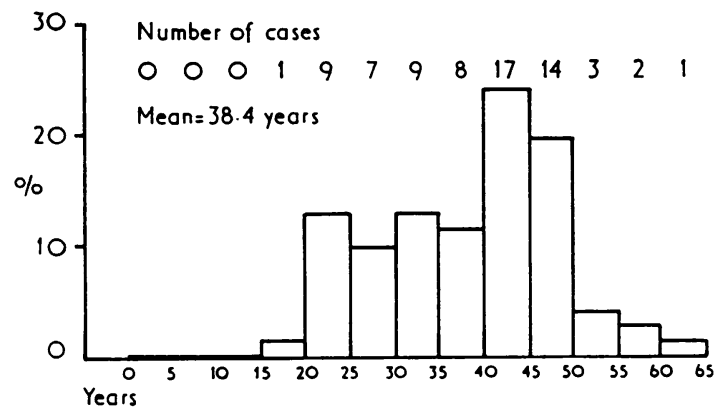

FIG. 2. Definite mesotheliomas with definite occupational asbestos exposure: survival after first exposure.

recognized that this would have been desirable (McEwen, Finlayson, Mair, and Gibson, 1970).

Figures 2, 3 and 4 illustrate time relationships with known asbestos exposure. In $85 \%$ of cases death occurred more than 25 years after first exposure, although the shortest period was three and a half years and the longest 53 years. There was no significant difference in the distributions of years of
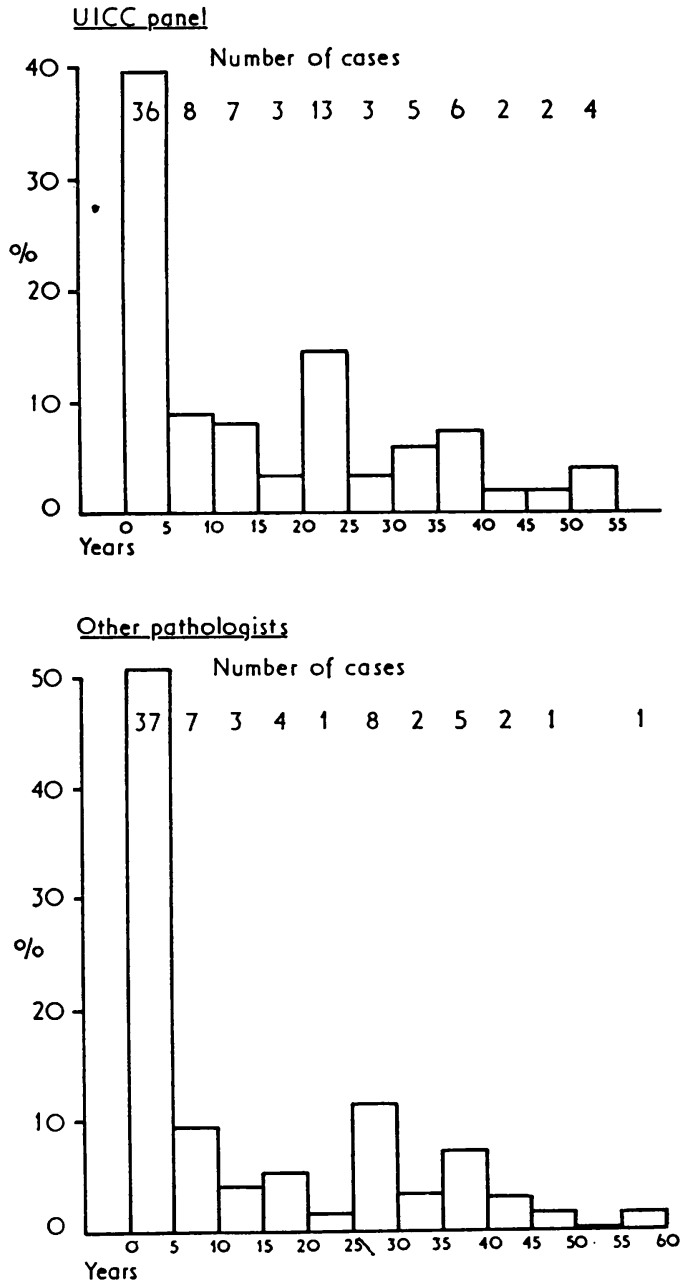

FIG. 3. Definite mesotheliomas with definite occupational asbestos exposure: survival after last exposure.

TABLE 7

TyPe of Asbestos involved in Occupational Asbestos ExPosure

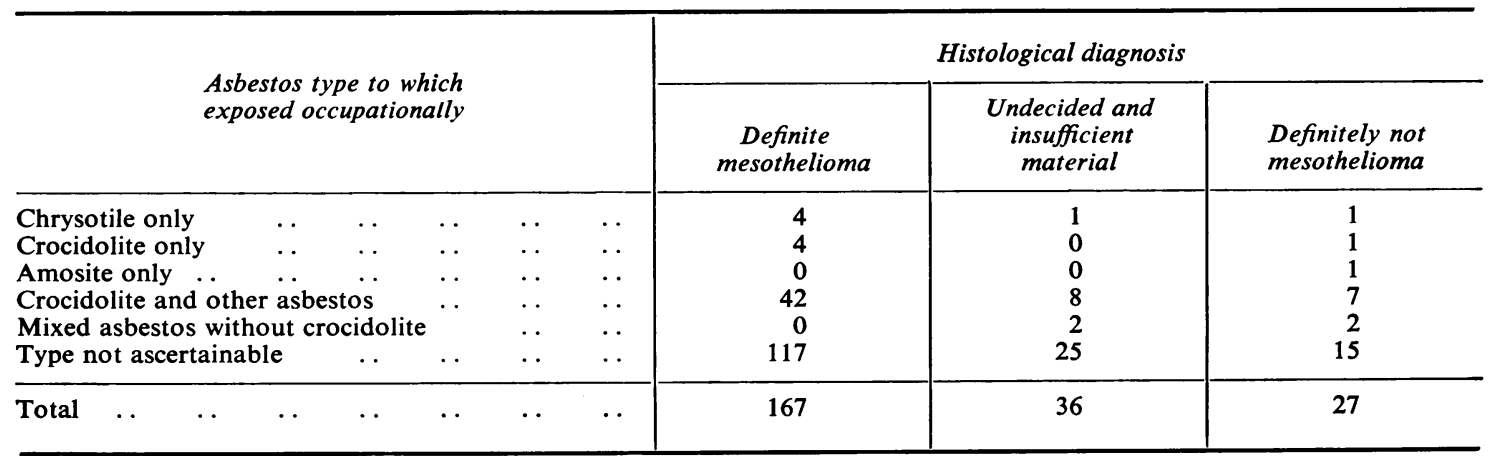



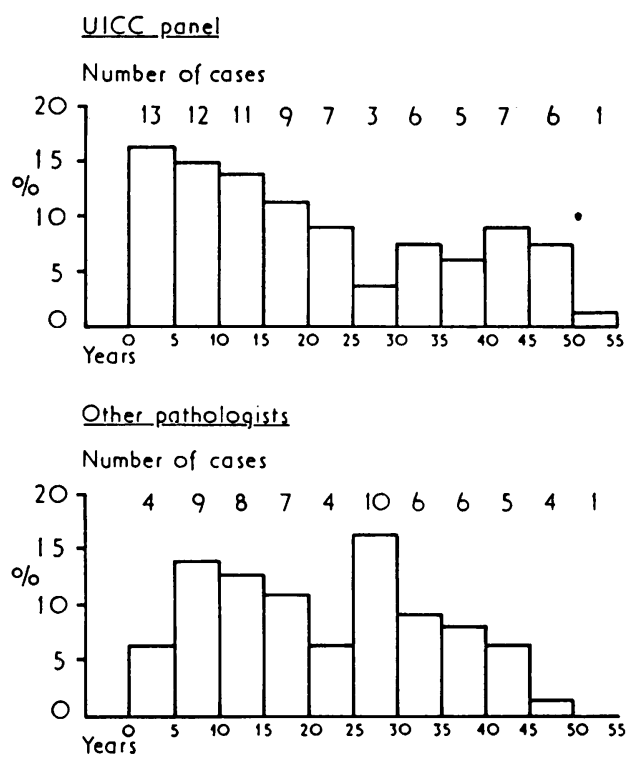

FIG. 4. Definite pleural mesothelioma: duration of occupational exposure to asbestos.

survival after first exposure in the two groups (mean age: UICC, 37.4 years; other pathologists, 38.4 years). The interval between last handling asbestos and death was under one year in about $40 \%$ cases but varied up to 52 years (one case). The duration of exposure was more widely spread, ranging from three weeks to over 50 years. Twelve per cent of cases had been exposed for under five years. The man with only three weeks' exposure died over half a century later.

Table 7 summarizes information regarding the type of asbestos, but this could be obtained in only a small proportion of subjects. Of the 50 subjects with 'definite mesotheliomas', where the types of asbestos to which they were exposed were known, 45 had been exposed to crocidolite. Of the group of 12 subjects diagnosed as 'definitely not mesothelioma' in which types of asbestos to which they had been exposed were known, eight had been exposed to crocidolite.

There is no significant difference between these two groups. In four cases of definite mesothelioma no exposure was known other than to chrysotile. A history of exposure to talc was obtained in seven subjects with definite mesotheliomas, but six of them had also been exposed to asbestos. It was not possible to identify the nature of the talc to which they had been exposed.

\section{Other evidence of asbestos exposure}

It is apparent that a history of occupational exposure to asbestos is frequently associated with the presence of asbestosis, asbestos fibre bodies, asbestos fibres or pleural plaques observed at necropsy or radiologically (Table 8). Ashcroft and Heppleston (1973) stress the importance of phase contrast microscopy and electron microscopy in searching for asbestos in tissues. The presence of pleural plaques does not always indicate asbestos exposure (Rous and Studeny, 1970). It is not possible, however, to observe a significant difference of asbestos exposure between subjects with definite pleural mesotheliomas and those subsequently categorized as definitely not pleural mesothelioma.

In four 'definite pleural mesotheliomas' corroborative evidence of asbestos exposure was found in the absence of occupational exposure histories. Of those subjected to 'hobby' or 'domestic' exposure (six cases) none showed corroborative features. Of those with 'neighbourhood' exposure (eight cases), two had asbestos bodies.

TABLE 8

Corroborative Evidence of Asbestos Exposure ${ }^{1}$ Related to Occupational ExPosure History and Notifications to Mesothelioma Register (Pleural Tumours only)

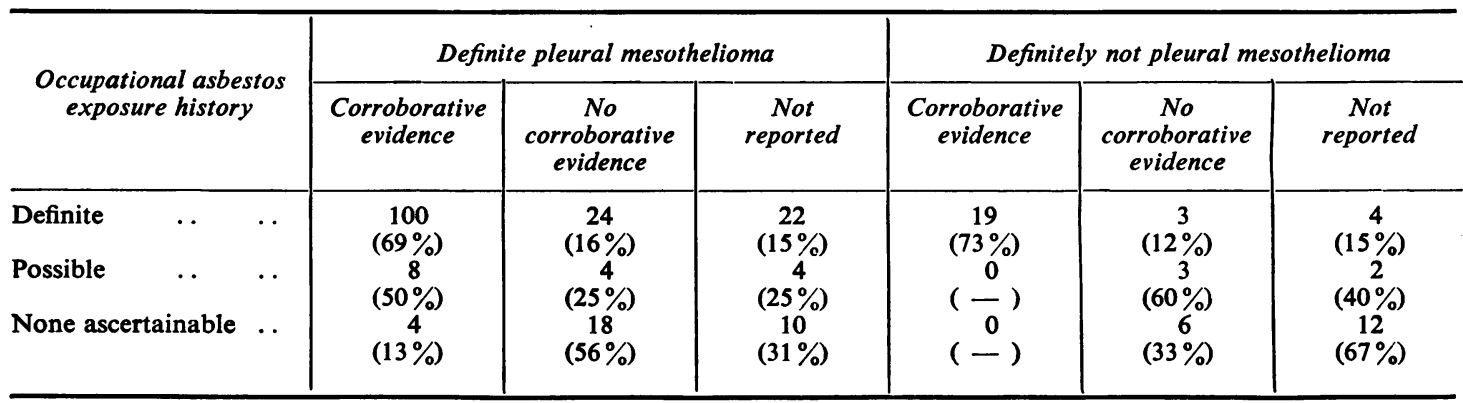

${ }^{1}$ Asbestosis, asbestos bodies, asbestos fibres or pleural plaques 


\section{Geographical distribution}

Tables $9 a$ and $9 b$ show the distribution and rate/ million per year of mesothelioma notifications and diagnoses in England and Wales and in Scotland. The Registrar General's standard regions are employed for England and Wales. Clydeside includes Dunbartonshire, Renfrewshire, Greenock, Glasgow, Hamilton, and Motherwell. The distributions are by no means related to population density. South western England, with a population of 3652 thousands, had a total of 22 definite cases (a rate of 2.97 cases/million per year) yet Plymouth, with a population of $250000,{ }^{1}$ had 13 cases, all with histories of occupational exposure to asbestos. The remainder of the region, with nearly 3 million population, produced nine mesotheliomas of which only four had a history of occupational exposure to asbestos (a rate of 1.5 cases/million per year).

${ }^{1}$ Assuming that Plymouth hospitals serve a population of twice that number, the rate would be 26 cases/million per year.
Merseyside, Clydeside, Tyneside, the South East Lancashire conurbation, and Greater London had an incidence of mesothelioma markedly greater than the national rate with deficits in the remainder of these regions. They have in common the presence of heavy asbestos-using industries.

The geographical distributions of cases, and of cases with occupational exposure, are shown in Figures 5 and 6.

\section{Discussion}

The recognition of diffuse mesothelioma depends on awareness and acceptance of the tumour as a pathological entity. The macroscopic appearance of a typical mesothelioma, resulting from its propensity to infiltrate serosal membranes, is best characterized by the well-developed pleural mesothelioma with permeation of visceral and parietal surfaces by a continuous layer of tumour. However, metastatic tumour in the pleura, usually from a primary adeno-

TABLE 9 (a)

Geographical Distribution of Numbers and Dates of Notifications and Confirmations of MesoTHELIOMA $1967-68$

\begin{tabular}{|c|c|c|c|c|c|c|c|c|}
\hline \multirow{2}{*}{\multicolumn{2}{|c|}{ Region $^{1}$}} & & & \multirow{2}{*}{$\begin{array}{c}1967 \\
\text { population } \\
\text { (millions) }\end{array}$} & \multicolumn{2}{|c|}{$\begin{array}{c}\text { Notifications to Register } \\
1967-68\end{array}$} & \multicolumn{2}{|c|}{$\begin{array}{c}\text { Definite mesotheliomas/ } \\
1967-68\end{array}$} \\
\hline & & & & & No. & Rate/million & No. & $\begin{array}{l}\text { Rate/million } \\
\text { year }\end{array}$ \\
\hline $\begin{array}{l}\text { Greater London } \\
\text { Rest of SE England }\end{array}$ & $\begin{array}{l}\cdots \\
\cdots\end{array}$ & $\begin{array}{l}\cdots \\
\cdots\end{array}$ & $\begin{array}{l}\cdots \\
\cdots\end{array}$ & $\begin{array}{l}7 \cdot 9 \\
9 \cdot 3\end{array}$ & $\begin{array}{r}111 \\
40\end{array}$ & $\begin{array}{l}7 \cdot 03 \\
2 \cdot 04\end{array}$ & $\begin{array}{l}58 \\
18\end{array}$ & $\begin{array}{l}3.67 \\
0.97\end{array}$ \\
\hline \multicolumn{2}{|c|}{$\begin{array}{l}\text { SE Lancashire conurbation } \\
\text { Merseyside conurbation } \\
\text { Rest of NW England .. }\end{array}$} & $\begin{array}{l}\cdots \\
\cdots \\
\cdots\end{array}$ & $\begin{array}{l}\cdots \\
\cdots \\
\cdots\end{array}$ & $\begin{array}{l}2 \cdot 5 \\
1 \cdot 4 \\
2 \cdot 9\end{array}$ & $\begin{array}{l}21 \\
33 \\
13\end{array}$ & $\begin{array}{r}4 \cdot 20 \\
11 \cdot 79 \\
2 \cdot 24\end{array}$ & $\begin{array}{r}16 \\
25 \\
8\end{array}$ & $\begin{array}{l}3 \cdot 20 \\
8 \cdot 93 \\
1 \cdot 38\end{array}$ \\
\hline $\begin{array}{l}\text { Tyneside . . . } \\
\text { Rest of N England }\end{array}$ & $\begin{array}{l}\cdots \\
\cdots\end{array}$ & $\begin{array}{l}\cdots \\
\cdots\end{array}$ & $\begin{array}{l}\cdots \\
\cdots\end{array}$ & $\begin{array}{l}0 \cdot 8 \\
2 \cdot 5\end{array}$ & $\begin{array}{l}14 \\
13\end{array}$ & $\begin{array}{l}8 \cdot 75 \\
2 \cdot 60\end{array}$ & $\begin{array}{l}9 \\
9\end{array}$ & $\begin{array}{l}5 \cdot 63 \\
1 \cdot 80\end{array}$ \\
\hline \multicolumn{3}{|c|}{$\begin{array}{l}\text { W Yorkshire conurbation } \\
\text { Rest of Yorks \& Humberside }\end{array}$} & $\begin{array}{l}\cdots \\
\cdots\end{array}$ & $\begin{array}{l}1 \cdot 7 \\
3 \cdot 0\end{array}$ & $\begin{array}{r}17 \\
5\end{array}$ & $\begin{array}{l}5.00 \\
0.83\end{array}$ & $\begin{array}{r}12 \\
3\end{array}$ & $\begin{array}{l}3 \cdot 53 \\
0 \cdot 50\end{array}$ \\
\hline $\begin{array}{l}\text { N Wales } \\
\text { SE Wales. . }\end{array}$ & $\begin{array}{l}\cdots \\
\cdots\end{array}$ & $\begin{array}{l}. \\
\therefore\end{array}$ & $\begin{array}{l}\cdots \\
\cdots\end{array}$ & $\begin{array}{l}0.8 \\
1.9\end{array}$ & $\begin{array}{r}3 \\
14\end{array}$ & $\begin{array}{l}1 \cdot 88 \\
3 \cdot 68\end{array}$ & $\begin{array}{r}3 \\
10\end{array}$ & $\begin{array}{l}1 \cdot 88 \\
2 \cdot 63\end{array}$ \\
\hline E Anglia . . & . & . & . & $1 \cdot 6$ & 6 & $1 \cdot 88$ & 3 & 0.94 \\
\hline $\begin{array}{l}\text { Clydeside } 2 \\
\text { Rest of Scotland }\end{array}$ & $\begin{array}{l}\cdots \\
\cdots\end{array}$ & $\begin{array}{l}\cdots \\
\cdots\end{array}$ & $\begin{array}{l}\cdots \\
\cdots\end{array}$ & $\begin{array}{l}1.7 \\
3.5\end{array}$ & $\begin{array}{l}43 \\
18\end{array}$ & $\begin{array}{r}12 \cdot 65 \\
2.57\end{array}$ & $\begin{array}{r}28 \\
6\end{array}$ & $\begin{array}{l}8 \cdot 24 \\
0.86\end{array}$ \\
\hline SW England & . & . & . & $3 \cdot 7$ & 30 & 4.05 & 22 & $2 \cdot 97$ \\
\hline $\begin{array}{l}\text { E Midlands } \\
\text { W Midlands conurbatic } \\
\text { Rest of W Midlands }\end{array}$ & $\begin{array}{l}\cdots \\
\text { on } \\
\ldots\end{array}$ & $\begin{array}{l}\cdots \\
\cdots \\
\cdots\end{array}$ & $\begin{array}{l}\cdots \\
\cdots \\
\cdots\end{array}$ & $\begin{array}{l}3 \cdot 3 \\
2 \cdot 4 \\
2 \cdot 6\end{array}$ & $\begin{array}{r}9 \\
11 \\
11\end{array}$ & $\begin{array}{l}1 \cdot 36 \\
2 \cdot 29 \\
2 \cdot 12\end{array}$ & $\begin{array}{l}3 \\
6 \\
6\end{array}$ & $\begin{array}{l}0 \cdot 45 \\
1 \cdot 25 \\
1 \cdot 15\end{array}$ \\
\hline England, Wales \& Scot & tland & . & .. & $53 \cdot 6$ & $412^{3}$ & $3 \cdot 84$ & $245^{3}$ & $2 \cdot 29$ \\
\hline
\end{tabular}

'Standard regions of Registrar General England \& Wales, except Clydeside

'Dunbartonshire, Renfrewshire, Greenock, Glasgow, Hamilton, Motherwell

'One subject who died in Australia not included 
TABLE 9 (b)

Geographical Distribution of Mesotheliomas associated with Occupational Asbestos Exposure and the Proportion of These Cases to all Cases of Mesothelioma

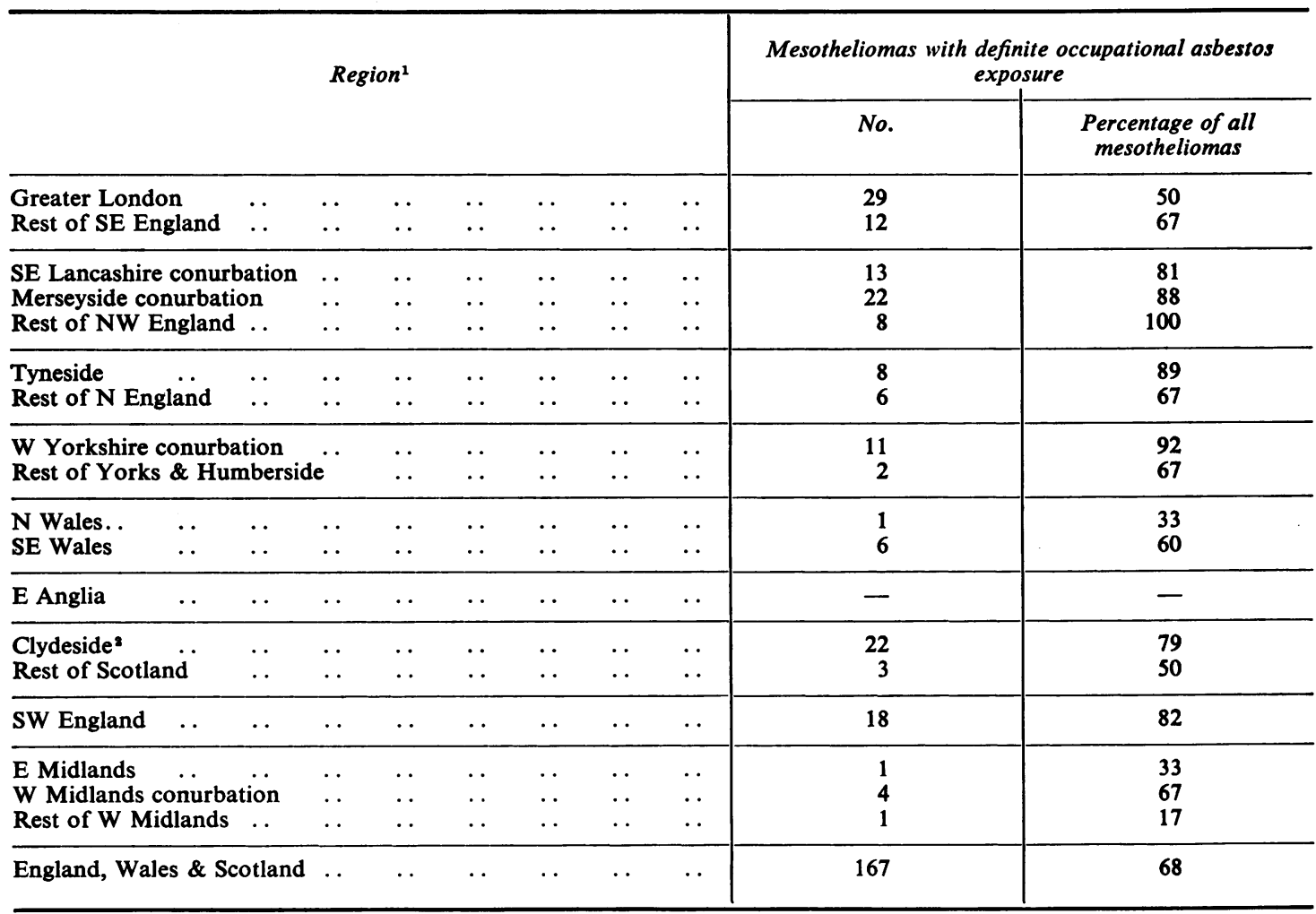

'Standard regions of Registrar General England \& Wales, except Clydeside

'Dunbartonshire, Renfrewshire, Greenock, Glasgow, Hamilton, Motherwell

carcinoma, can produce widespread sheet-like growth resembling late diffuse pleural mesothelioma. Histologically the cellular and intercellular characteristics can be highly equivocal. The UICC pathologists' panel criteria for reaching a decision were modified in the course of the survey (see Appendix) and have not finally been decided (McCaughey and Oldham, 1974).

Willis (1952) cautioned against accepting the diagnosis of mesothelioma until, by careful search, an alternative primary neoplasm had been excluded. In a series of 3771 necropsies Cameron, Litton, and Lyon (1961) found a prevalence of primary carcinoma multiplex of $1.2 \%$. In the present series there were three with additional primary neoplasms in the 246 'definite' cases (one with carcinoma of the stomach, another with carcinoma of the bronchus, and the third with myelogenous leukaemia). This represents a prevalence of carcinoma multiplex of $1.2 \%$. Sections referred to the UICC pathologists had previously been studied by other pathologists who had not necessarily made a diagnosis of mesothe- lioma. In 182 cases where adequate histological material had been studied by UICC pathologists they made a diagnosis of mesothelioma in $134(74 \%)$, were undecided in $10 \%$, and made an alternative diagnosis on 30 occasions $(16 \%)$. The concordance of diagnosis between UICC and other pathologists is greater in view of the fact that a number of sections were referred to the UICC panelists for a second opinion when the other pathologists had said the condition was not mesothelioma but an asbestos occupation history had been obtained by the clinicians.

In those cases with adequate histological material, not referred to the UICC panel (186 cases), a pathological diagnosis of definite mesothelioma was made in $112(60 \%)$.

The submission of sections to the UICC panel varied in different parts of the country. In Greater London 77 out of 111 cases were referred (69\%), compared with only 12 out of 61 cases in Scotland $(20 \%)$.

The number of cases diagnosed is unlikely to be 


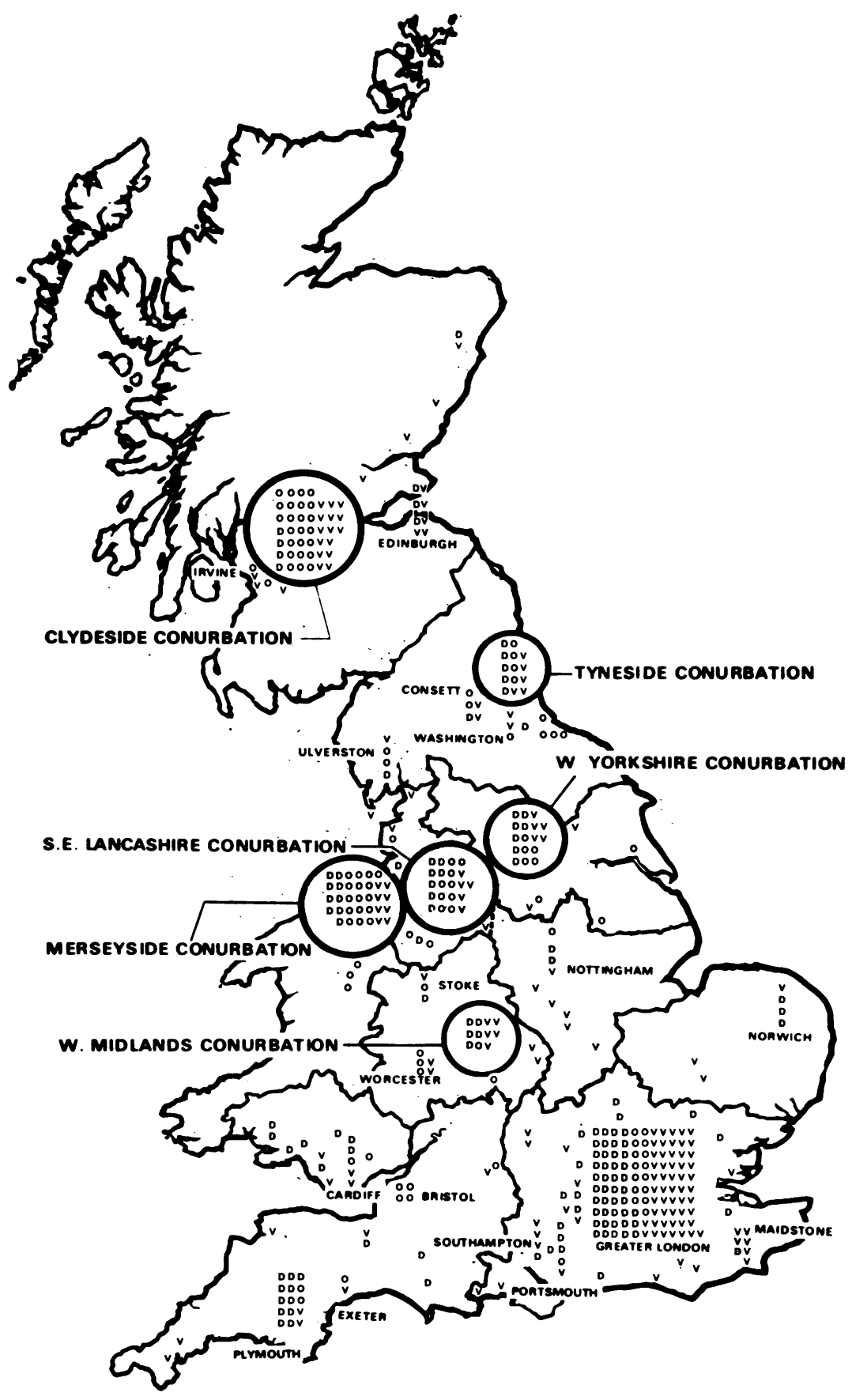

FIG. 5. Geographical distribution of notifications and confirmations of mesothelioma 1967-68 (standard regions employed by Registrar General except Clydeside which includes Dunbartonshire, Renfrewshire, Greenock, Glasgow, Hamilton and Motherwell): $\mathrm{D}=$ definite mesothelioma-UICC Panel; $\mathrm{O}=$ definite mesothelioma-other pathologists; $\mathrm{V}=$ other diagnoses. 


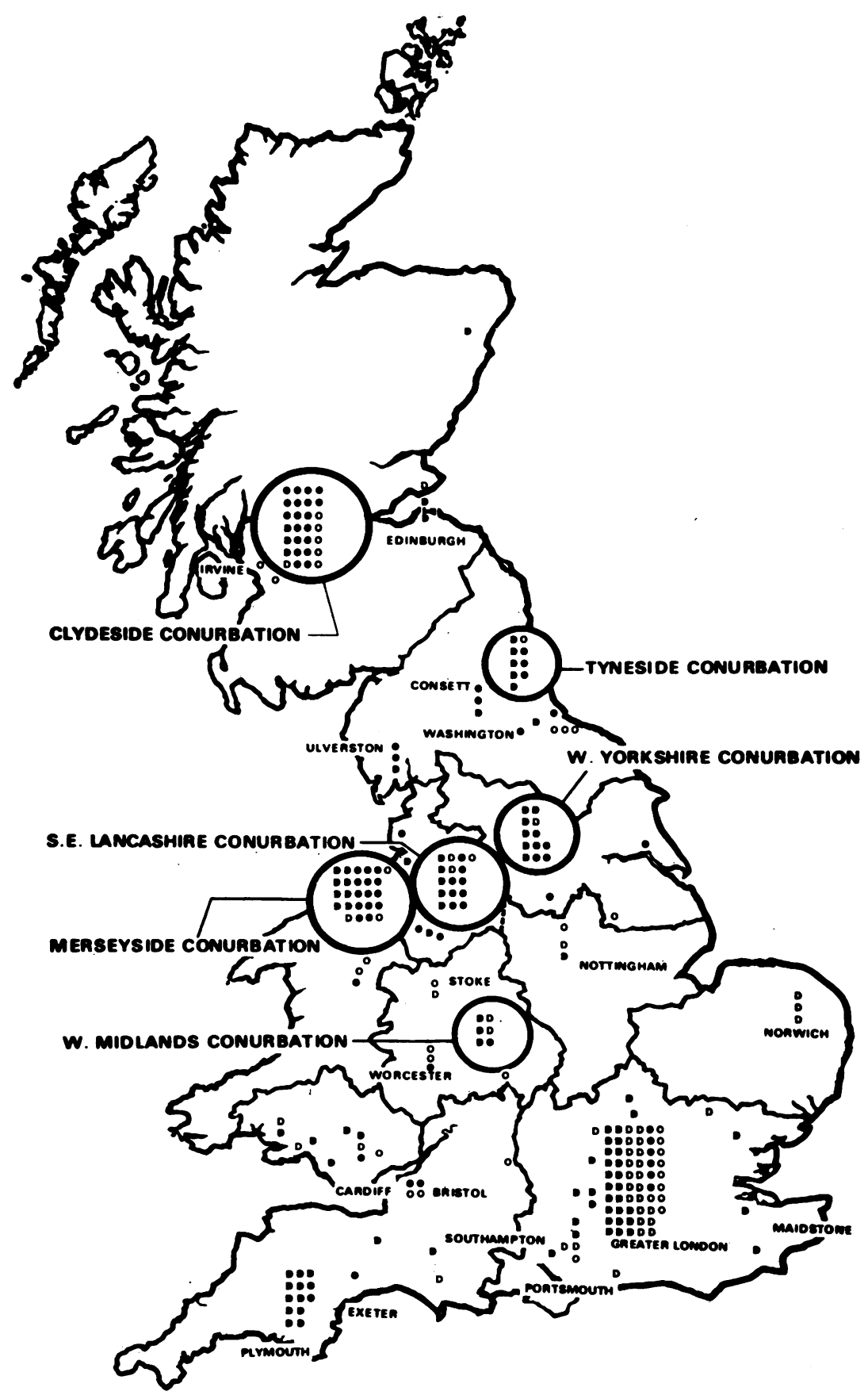

FIG. 6. Geographical distribution of definite mesotheliomas and associated occupational asbestos exposure: $\mathbf{D}=$ definite mesothelioma-UICC Panel; $\mathbf{O}=$ definite mesothelioma -other pathologists; $\mathbf{Q}=$ = definite occupational exposure. 
overstated by the inclusion of diagnoses by other pathologists as the tumour in general tends to be underdiagnosed (Newhouse and Wagner, 1969). These authors reviewed the causes of death in a group of workers at an asbestos factory and found 19 mesothelial tumours in 84 cases in which adequate pathological material was available, but of which only four cases had previously been recognized.

The observed incidence of definite mesothelioma in this series was approximately 120 per year. For the reasons stated above this figure may considerably understate the true incidence.

The proportion of mesothelial tumours in which asbestos exposure cannot be implicated has been quoted by Wagner et al. (1971) as 10 to $15 \%$. The geographical distribution in the present series showed that in Greater London, where there are substantial asbestos-using industries, $29(50 \%)$ of 58 definite mesotheliomas had no ascertainable occupational asbestos exposure. Overall in the study there were 38 cases $(15.0 \%$ of all mesothelial tumours) lacking evidence of asbestos exposure.

In this study the briefest occupational exposure to asbestos associated with a mesothelial tumour was three weeks, but if asbestos was a cause of mesothelioma it cannot be assumed that lesser exposures are safe.

Under industrial conditions prevailing in England and Wales and in Scotland the significance of crocidolite in the aetiology of mesothelioma could not be determined.

Planning, administration, and field work were carried out by all the members of the Medical Services Division (now Employment Medical Advisory Service) of the Department of Employment between 1967 and 1971. The assistance of the following is gratefully acknowledged: the Registrars General for England and Wales and Scotland; HM coroners and their officers; hospital records officers and the staff of the Pneumoconiosis Medical Panels who provided information and leads as to further sources of information; the pathologists (including the members of the British panel of UICC pathologists for the standardization of the diagnosis of mesothelial tumours); Dr. K. F. W. Hinson and members of his department at the Brompton Hospital who circulated slides to the panel; Dr. J. C. Gilson, Dr. J. C. Wagner, and other members of the staff of the MRC Pneumoconiosis Unit, Penarth; Professor P. C. Elmes and Professor $W$. R. Lee who read the draft manuscript and made a number of helpful suggestions; Mr. R. V. Hayball and Mr. M. T. E. Houghton of the Employment Medical Advisory Service for their meticulous record keeping; the late Dr. D. C. Lindars who assisted with the final draft. The following members of the Medical Services Division undertook the laborious yet delicate work of tracing: J. D. Bell, E. S. Blackadder, M. J. Catton, H. J. Davies, T. W. Davies, A. T. Doig, K. J. Dunlop, L. E. Euinton, M.D. Kipling, G. L. Ritchie, G. F. Smith, J. B. L. Tombleson, D. G. Trott, J. G. S. West, and R. Whitelaw.

\section{References}

Ashcroft, T. and Heppleston, A. G. (1970). Mesothelioma and asbestos on Tyneside-a pathological and social study. In Proceedings of the International Conference on Pneumoconiosis, Johannesburg, 1969, edited by H. A. Shapiro, pp. 177-179. Oxford University Press, Cape Town.

- (1973). The optical and electron microscopic determination of pulmonary asbestos fibre concentration and its relation to the human pathological reaction. Journal of Clinical Pathology, 26, 224-234.

Cameron, J. M., Litton, A., and Lyon, D. S. (1961). Primary carcinoma multiplex. Journal of Clinical Pathology, 14, 574-577.

Hammond, E. C. (1966). Smoking in relation to the death rates of one million men and women. In Epidemiological Approaches to the Study of Cancer and Other Chronic Diseases, edited by W. Haenszel, p. 127. National Cancer Institute Monograph, No. 19. National Cancer Institute, Bethesda, Maryland, U.S.A.

Hourihane, D. O'B. (1954). The pathology of mesotheliomata and an analysis of their association with asbestos exposure. Thorax, 19, 268-278.

Lloyd Davies, T. A. (1970). Annual Report of H.M. Chief Inspector of Factories 1969, p. 57, Cmmd 4461. H.M.S.O., London.

McCaughey, W. T. E. (1965). Criteria for diagnosis of diffuse mesothelial tumours. Annals of the New York Academy of Sciences, 132, 603-613.

- and Oldham, P. D. (1974). Diffuse mesotheliomas morbid anatomical and histological criteria, including observer variation in histological diagnosis. Proceedings of the Working Group to review the Biological Effects of Asbestos. International Agency for Research on Cancer, W.H.O., Lyon (in press).

McEwen, J., Finlayson, A., Mair, A., and Gibson, A. A. M. (1970). Mesothelioma in Scotland. British Medical Journal, 4, 575-578.

Newhouse, Muriel L., Berry, G., Wagner, J. C., and Turok, Mary, E. (1972). A study of the mortality of female asbestos workers. British Journal of Industrial Medicine, 29, 134-141.

- and Wagner, J. C. (1969). Validation of death certificates in asbestos workers. British Journal of Industrial Medicine, 26, 302-307.

Registrar General (1970). Statistical Review of England and Wales for the Year 1968, Part I, Medical, p. 124. H.M.S.O., London.

Rous, V. and Studeny, J. (1970). Aetiology of pleural plaques. Thorax, 25, 270-284.

Selikoff, I. J., Hammond, E. C., and Churg, J. (1970). Mortality experience of asbestos insulation workers. In Proceedings of the International Conference on Pneumoconiosis, Johannesburg (1969), edited by H. A. Shapiro, pp. 180-186. Oxford University Press, Cape Town.

Senior Medical Inspector's Advisory Panel Memorandum (1968). Problems arising from the Use of Asbestos. H.M.S.O., London.

Smither, W. J., Gilson, J. C., and Wagner, J. C. (1962). Mesotheliomas and asbestos dust (letter). British Medical Journal, 2, 1194-1195.

Thomson, J. G. (1970). The pathological diagnosis of malignant mesothelioma of the pleura and peritoneum. In Proceedings of the International Conference on Pneumoconiosis, Johannesburg (1969), edited by H. A. Shapiro, pp. 150-154. Oxford University Press, Cape Town.

Wagner, J C., Gilson, J. C., Berry, M. A., and Timbrell, V. (1971). Epidemiology of asbestos cancers. British Medical Bulletin, 27, 71-76.

- Munday, D. E., and Harington, J. S. (1962). Histochemical demonstration of hyaluronic acid in pleural 
mesotheliomas. Journal of Pathology and Bacteriology, 84, 73-77.

- Sleggs, C. A., and Marchand, P. (1960). Diffuse pleural mesothelioma and asbestos exposure in North Western Cape Province. British Journal of Industrial Medicine, 17, 260-271.

Whitwell, F. and Rawcliffe, Rachel M. (1971). Diffuse malignant pleural mesothelioma and asbestos exposure. Thorax, 26, 6-22.

Willis, R. A. (1952). The Spread of Tumours in the Human Body, 2nd ed., p. 55. Butterworths, London.

Received for publication May 17, 1973

Accepted for publication July 20, 1973
If the two opinions lead to a blank entry above then the specimen should be sent to the two other readers and a combined diagnosis made on the basis of four readings. There are many possibilities from four readings but the combined diagnosis should follow the majority if there is a clear one and otherwise be undecided. The following rule is sufficient to determine all cases of four readings: score a definite as 1 point, probable as $\frac{1}{2}$, possible as 0 , not as -1 ; then add up the four scores and if the total is greater than or equal to $1 \frac{1}{2}$ the diagnosis is Definite, between -1 and +1 inclusive it is Undecided, less than or equal to $-1 \frac{1}{2}$ is Not a mesothelioma.

\section{Addendum}

The Mesothelioma Register, which in 1967 and 1968 recorded cases from all available sources, has since continued with notifications of deceased cases only. The following table gives details of notifications (subject to confirmation) for the years up to 1971, figures for the years 1967 and 1968 being included on a similar basis for comparison.

\section{APPENDIX}

The UICC Panel of Pathologists and diagnostic criteria

A British panel of pathologists specializing in the diagnosis of mesothelial tumours was formed unofficially in 1963 and consisted of Dr. K. F. W. Hinson, Dr. F. Whitwell, Professor W. F. E. McCaughey, and Dr. J. C. Wagner.

From 1963 to 1967 all cases were examined by all members of the panel and a majority opinion was arrived at. Subsequently the panel was constituted as a UICC panel. From 1967 panellists decided whether the diagnosis was definitely mesothelioma, definitely not mesothelioma or whether there was insufficient histological material, only referring material to another member or members of the panel in case of doubt. After mid-1968 the policy was adopted that all cases referred to the panel should be seen by at least two members and that if there was a difference of opinion a third opinion should be sought. In mid-1971 the following protocol was designed for combined panel diagnosis. Two opinions are necessary for diagnosis and these two opinions should be combined as below:
Notifications to the Mesothelioma Register (DeATh CASES) 1967-71

\begin{tabular}{l|rrrrr}
\hline $\begin{array}{l}\text { Sources of } \\
\text { notification }\end{array}$ & 1967 & 1968 & 1969 & 1970 & 1971 \\
\hline $\begin{array}{l}\text { Death certificate } \\
\begin{array}{l}\text { Cancer Registry } \\
\text { Industrial injury } \\
\text { data }\end{array}\end{array}$ & 91 & 189 & 126 & 165 & 124 \\
$\begin{array}{l}\text { Other } \\
\text { Total }\end{array}$ & 39 & 3 & 6 & 3 & -3 \\
\hline & 163 & 233 & 157 & 184 & 138 \\
\hline
\end{tabular}

'Not so certified at death

${ }^{2}$ Not on death certificate or cancer registration

In the short period studied it is not possible to observe a significant trend. The large number of cases notified in 1968 may have resulted from the publicity and vigilance generated by the survey. If the impression of a falling off in notifications is confirmed then whether this will be due to a change in the prevalence of the disease or to a change in vigilance will require to be evaluated.

\begin{tabular}{|c|c|c|c|c|c|}
\hline & & \multicolumn{4}{|c|}{ Second opinion } \\
\hline & & Definite & Probable & Possible & Not \\
\hline First opinion & $\begin{array}{l}\text { Definite mesothelioma } \\
\text { Probable mesothelioma } \\
\text { Possible mesothelioma } \\
\text { Not a mesothelioma }\end{array}$ & $\begin{array}{c}\text { Definite } \\
\text { Definite } \\
-\end{array}$ & $\begin{array}{l}\text { Definite } \\
\text { Undecided } \\
\text { Undecided } \\
\end{array}$ & $\begin{array}{l}\text { Undecided } \\
\text { Undecided } \\
\text { Not }\end{array}$ & $\begin{array}{l}- \\
\text { Not } \\
\text { Not }\end{array}$ \\
\hline
\end{tabular}

